\title{
Taking Liberties: Academic Freedom and the Humanities
}

DOUG STEWARD

It is absolutely essential that the learned community at the university... contain a faculty that is independent of the government's command with regard to its teachings; one that, having no commands to give, is free to evaluate everything, and concerns itself with the interests of the sciences, that is, with truth: one in which reason is authorized to speak out publicly. For without a faculty of this kind, the truth would not come to light (and this would be to the government's own detriment); but reason is by its nature free and admits of no command to bold something as true (no imperative "Believe!" but only a free "I believe").

-Immanuel Kant

The Western history of academic freedom begins with Plato's account of the trial of Socrates, who was executed after spurious charges of his teaching's impiety and corruption of youth scandalized his fellow citizens. More recently, in 1951, William F. Buckley played Meletus to what he called "academic freedomites" (146) in God and Man at Yale: The Superstitions of "Academic Freedom." Buckley hailed the 1950s as an era of consumer rule in higher education, asserting that trustees and alumni have not only the right but "the duty to 'interfere" " when a university does not urge pro-capitalist, pro-Christian viewpoints on students (115). University faculty members would necessarily comply since, as Buckley put it, "every citizen in a free

The author is associate director of MLA Programs and the ADE. A version of this article appeared in the Winter-Spring 2007 issue of the ADE Bulletin. 
economy, no matter the wares that he plies, must defer to the sovereignty of the consumer" (185). Elaborating on this view, John Chamberlain wrote, "in a democracy, the customer (who pays the bills) must have the right to exercise his free choice when he is out shopping in the market place. The autonomy of the customer should hold whether he is buying toothpaste, tennis rackets-or education for his children" (emphasis added). This consumerist attitude did not originate in the 1950s: Kant mocked something like it in 1784 when he wrote, "I need not think, so long as I can pay" ("An Answer" 54). Buckley considered it morally incumbent on the trustees of Yale to direct the economics faculty to promote individualism and free markets, which faculty members' expertise in economics apparently left them reluctant to do voluntarily. He was also displeased by what he considered the lewd content of some courses and by an ambient irreverence toward religion. In short, he objected to the Yale faculty's impiety and corruption of youth and promoted a moralizing view of education as a commodity subject to the sovereignty of consumer whim, a view that has taken root in public discourse in the intervening years. The view is more than half a century old, its roots stretching back well before the culture wars of the 1980s; the feminist, gay, and Chicano/a movements of the 1970s; and the black civil rights movement of the 1960s-moments when certain myopic commentators would have us believe that politics illicitly entered higher education through the machinations of one disruptive minority or another. Sweepingly, we might ask, with Jacques Derrida, "has impiety not always been, and thus still is today, the principal and surest charge against any disquieting thinker?" (Du droit 46; my trans.).

\section{Prevarications of the Unfreedomites}

After decades of development by a network of funding agencies, think tanks, and activist organizations, consumerist rhetoric is now taken for granted even at the highest levels of government. In a recent interview, Margaret Spellings - the United States Secretary of Education, whose daughter attends Davidson College-referred to herself, off-handedly, as a concerned "customer of a private college" ("Time"). This customer-service mentality's failure to distinguish a substantive difference between purchasing toothpaste at a drugstore and paying tuition to a college is troubling. The implication in Spellings's and Chamberlain's view that they, rather than the students, are the ones being served is unfortunate and symptomatic of class-specific assumptions about money and tuition: my money buys my child the commodity of my class legacy.

Combined with a moralizing political agenda, such as Buckley's, some 
versions of educational consumerism are ominous. Riled by allegations of impiety and corruption of youth, in March 2006 Arizona legislators put forward a bill that would have required professors at state institutions to provide alternative assignments for students who were offended by content in course materials. Linda Gray (Republican, Phoenix), chair of the Arizona senate's Higher Education Committee, declared, "[Professors] contribute to society accepting immoral behavior." Considering Gray's position on the Higher Education Committee, this is a startling judgment. "(The classroom) is where they get to the mind," she warned (qtd. in Cronin). This bill is only one of many recently inspired by David Horowitz's socalled Academic Bill of Rights, which purports to ensure ideological balance on university faculties by stripping the faculty of the right to choose whom to hire based solely on the person's professional qualifications and the institution's educational goals. Not always articulated in explicitly consumerist terms, this profoundly anti-intellectual politicization of faculty hiring typifies attempts to immolate academic freedom in its own name: by declaring the importance of ensuring an Orwellian "intellectual diversity" even at the cost of the faculty's expert self-determination.

In their worst forms, such anti-intellectual movements seek not merely to exercise the right to critique how universities run their affairs but to put the stopper on controversial scholarship and teaching, to defund the institutions sheltering controversial professors, and to institute a kind of academic unfreedom closely monitored by trustees, governors, alumni, legislators, parents, and affluent think tanks with well-defined agendas. Founded by Lynne Cheney, among others, the American Council of Trustees and Alumni (ACTA) is an especially menacing antifaculty activist organization that has received more than $\$ 2$ million in grants in the past eight or nine years from such right-wing agencies as the Sarah Scaife, the Earhart, and the Lynde and Harry Bradley Foundations (Media Transparency). ACTA takes special interest in the "interpretive" fields of the humanities and social sciences and hastened to profit politically from the attacks on 9/11, publishing an inflammatory pamphlet, Defending Civilization: How Our Universities Are Failing America and What Can Be Done about It, on its Web site only two months after the terrorist strikes. In that pamphlet, ACTA's principal employees, Jerry Martin and Anne Neal, applauded United States military action on the basis of the general public's anger and patriotism immediately following 9/11 (1) — not on the basis of military strategy or intelligence community recommendation-and impugned the reputation and character of any professor who wondered aloud about the hijackers' motives, discussed critically the history of United States foreign 
policy in the Middle East or Latin America, encouraged the study of Islam, or distinguished between proximate and ultimate causes. Throughout the pamphlet, debate on terrorism and $9 / 11$ is cast in the crude terms of those who support the president and oppose terrorism and those who oppose the president and support terrorism, those who "[call] evil by its rightful name" and those who "BLAME AMERICA FIRST" (1, 3). Defending Civilization is essentially a compilation of professors' (sometimes intemperate) remarks taken out of context and as such was widely understood to be a kind of blacklist. The pamphlet prompted Senator Joseph Lieberman to write to ACTA to object to it and its unauthorized insinuation of his support and to ask that his name be removed from ACTA's Web site as a cofounder. The council then added an acknowledgment that no public figure, including Lynne Cheney and Lieberman, "had endorsed or been asked to endorse" the pamphlet. This devious maneuver allowed the council to maintain its pretense of bipartisanship, appeared to lift the pamphlet above the fray of politics, and concealed the fact that Lieberman had explicitly denounced it.

ACTA has never said anything about the innumerable xenophobic responses to 9/11, but in a series of documents stretching back a decade, such as The Shakespeare File (Martin, Neal, and Nadel), it has argued that the faculty has forfeited its right to academic freedom because of its moral relativism, classroom politicking, and low standards and because it has eschewed the concomitant responsibilities, principally respect for the political views of right-wing students when they differ from professors'. For their part, literature professors are allegedly teaching everything but literature (Martin, Neal, and Nadel 8-9; ACTA, How Many 7). ACTA never establishes that faculty members do not teach (classic) literature, only that they often have recourse to fields other than literature in their teaching. Literature has not been removed from language and literature curricula, but most folks nowadays do consider formalist criticism only one set of tools and agree with Theodor Adorno's view that "if you attempt to understand a thing purely on its own terms, then you will understand nothing" (13). As a result, the study of literature and its contexts is broadly conceived, often in interdisciplinary ways.

In fact, interdisciplinary work and ethnic studies in particular figure importantly in ACTA's latest salvo, provocatively titled How Many Ward Churchills?, which is again largely a compilation of quotations with minimal exposition of argument. The title's question is rhetorical and leads to the further rhetorical questions, "Do professors in their classrooms ensure a robust exchange of ideas designed to help students to think for them- 
selves? Or do they use their classrooms as platforms for propaganda, sites of sensitivity training, and launching pads for political activism?" (foreword). ACTA President Anne Neal is promptly quoted assuring us that she supports academic freedom but intoning that it ends where professors "abuse the special trust they are given to respect students' academic freedom to learn." Even as ACTA admits that "Churchill has followed an exceptional path to academic prominence," it claims that "he is not at all unusual," stating explicitly that he represents faculty members' political radicalism, especially where $9 / 11$ is concerned. More subtly, ACTA's logic of guilt by association suggests Churchill represents faculty members' lack of rigor, since his scholarship was under investigation by an ad hoc committee. The pamphlet pretends to tell us what professors are doing in classrooms, but there is no evidence that anyone from ACTA visited a single classroom in preparing the hefty pamphlet, which relies exclusively on material available on the Internet, such as course descriptions.

I'll only highlight a couple of telltale moments in How Many Ward Churchills? (There is so much so fundamentally wrong with ACTA's pamphlets that one must take them sentence by sentence.) Let me underscore at the outset that this pamphlet connects Churchill's exceptionally illconsidered comments on $9 / 11$ to all manner of academic study that has no connection whatsoever to 9/11. ACTA begins with a number of courses that treat questions of race and ethnicity, taking these as the exemplary evil of what it calls "the politicized liberal arts curriculum" (6). In a sense, the tract is an objective description: although it takes a sententious, patronizing tone and imputes traitorous motives to professors, ACTA does not seem to distort the actual course descriptions it cherry-picks from the Web. Instead, it operates by unarticulated argument, as when it declares of several courses on race and ethnicity, "The rationale for such courses stems from the belief that it is the professor's job to challenge students' unexamined assumptions" (6). In context, this observation is meant, prima facie, to horripilate readers who never suspected such perfidy in an American classroom. But in fact it is the professor's job to challenge students' unexamined assumptions-especially on questions of particular obfuscation in the arena of popular opinion, such as race. Questioning unexamined assumptions has been the professor's job since ancient Greece; it epitomizes the Socratic method. As Gary Pavela concisely explains, students' own academic freedom is embedded within the maieutic practice:

[A teacher] asserts a belief or hypothesis to invite refutation. The teacher may have superior knowledge and experience but encourages students to raise doubts and fresh perspectives to define truth anew-a method 
rooted in a synthesis of free inquiry and collaboration that could be regarded as the beginning of the scientific method.

The general model of learning as dialogue is the dominant one today in many disciplines, having replaced the lecture from on high some time ago. ACTA pretends to defend the Western tradition. Instead, it is not only ignorant of the most basic and ancient pedagogical practice of that tradition but actually gets pedagogy dead wrong and thus misrepresents courses on race and ethnicity.

Another example involving race and ethnicity, this time in reference to a course on the Third World and the West at Duke University, further illustrates ACTA's mode of argument by association. Of the course ACTA's concluding sentence remarks, "Assigned texts include Ward Churchill's $A$ Little Matter of Genocide - a book whose claims about the U.S. Army's treatment of Native Americans are implicated in the University of Colorado's investigation of whether Churchill has committed academic fraud" (How Many 6). This rhetorical legerdemain epitomizes the insinuation of guilt that ACTA specializes in. Although Churchill's scholarship was at the time under review, ACTA, without (to all appearances) picking up a single one of his books, not to mention having no one on staff with expertise in $\mathrm{Na}$ tive studies, effectively renders judgment on Churchill's work. At the same time, without committing itself to any positive statement, ACTA implies that a course with Churchill on the syllabus is by definition a bad course and-most remarkably—that the United States Army probably treated Native Americans just fine (since Churchill, who asserted otherwise, was under investigation for academic fraud ...). In terms of evidence this argument by insinuation is null, but it is efficient sophistry nonetheless.

Like Horowitz, ACTA sometimes declares its position to be politically neutral; at other times, it promotes "intellectual diversity," which means conservative professors who teach from a conservative viewpoint. ACTA never says which conservative courses would provide for intellectual diversity; it only fingers the courses that it finds objectionably uniform in their leftist slant. But we do know exactly what those courses "homogeneously" opposed-social injustice, domestic violence, monolingualism, white power, jingoism, xenophobia, male supremacy, slavery, racism, poverty, homophobia, misogyny, orientalism, genocide, spread-eagle foreign policy, and Third World exploitation. (ACTA examined only the humanities and social sciences, the disciplines most likely to be concerned with human rights and wrongs. The natural sciences, not to mention schools of business, engineering, medicine, and so on, are wholly absent.) Here too ACTA follows the example of Buckley, who came very close to condemning 
Yale for not employing any professors with "anti-Semitic, anti-negroid prejudices" who would espouse "the anthropological superiority of the Aryan," since these were "value-judgments ... upheld by various scholars not only in the past but in the present day [1951] as well" (148). Buckley and ACTA reproach humanists for their moral relativism, but what they mean is that they don't approve of humanists' moral vision. Indeed, it is not nihilistic moral relativism to take well-reasoned positions on questions of human rights and responsibilities, as professors routinely do; it is nihilistic moral relativism, or something worse, to insinuate that Native Americans were treated well by the United States Army or that Aryanism might legitimately counterbalance antiracism in college curricula since both are "valuejudgments." Such is the pedigree of today's push for intellectual diversity.

It will not do to allow insinuation and appeals to prejudice to govern public debate on higher education. Opponents of academic freedom specialize in the prevaricating attack, and their reluctance to advocate for anything more specific than lots of Shakespeare instead of what they attack is a weakness in their assault on the faculty's autonomy. At every opportunity, such critics should be asked to specify the details of their preferred educational program or to specify points on which they dispute a particular work of scholarship. Likewise where they imply that racial and ethnic discrimination no longer exists, or never existed, they should be confronted with evidence to the contrary and required to respond to it. Such critics' ignorance or misrepresentation of the history of the university and of academic freedom should be highlighted. As Toni Morrison reminds us, the people have a right to expose "language that ... tucks its fascist boots under crinolines of respectability and patriotism as it moves relentlessly toward the bottom line and the bottomed-out mind."

We should also assert that professors in the humanities and social sciences promote certain values over others in the classroom, when they do, because their professional expertise leads them to conclude that some values are not only less desirable but also destructive. These are not questions of mere opinion. Biologists oppose the imposition of "intelligent design" on their curricula because it does not meet relevant standards in biology, not because they are biased. Astronomers hire more astronomers, rather than astrologists, because they share hard-earned scholarly values with the former, not the latter. Intelligent design and astrology are beliefs, not science. Likewise, scholars in the humanities and social sciences do not promote, for example, the beliefs of racism in their courses, because their professional study of the subject matter, to which they dedicate their lives, has led them to conclude that racism is a set of human values and practices worthy of opposition and that students studying, say, The Tempest or La 
condition bumaine need to know something about colonialism's history in order to understand the meaning of those texts. Humanists, in particular, are trained to make complex judgments about human values and the human creations that give them form. That's what humanists do, and the critique of "the human" itself is one of the most compelling avenues of contemporary thought.

I stress that ACTA plans to abolish existing due process for hiring and firing professors. To counter what it considers biased teaching — and taking another page from Buckley's God and Man at Yale-ACTA promotes the hierarchical takeover of higher education faculties through strong, handson lay governance by trustees; gubernatorial and legislative intervention; and strategized alumni giving that places strict limitations on how funds can be used, effectively installing donors as curriculum planners. These are not ACTA's hypothetical remedies to be implemented only if the reforms that ACTA advocates are not undertaken through more traditional means. According to Neal's think-tank mantra for state legislatures, strong lay governance is a sine qua non of higher education in a democracy, but Neal's oft-repeated statement is false. Lay governance did not spring from the soil of democracy as such. The lay board of governance is a quirk of American higher education that arose not at all from democracy per se but from the necessity of denominationally affiliated institutions' ability to survive in the United States' religiously plural society: to temper sectarian dogmatism (Hofstadter 122-23). Ironically, ACTA's promotion of strong lay governance by trustees is today designed to do the opposite: to govern by dogmatism. In doing so, ACTA would subordinate the systematic pursuit of truth and knowledge by thousands of highly trained and certified experts to the personal opinion of a tiny number of wealthy persons who are more likely to have a business background than an academic one and among whom women and people of color are grossly underrepresented (Fain). As Richard Hofstadter noted in the 1950s, the "system of lay government has created special problems for free teaching and scholarship in America" (120); it is a legacy that ACTA would like to see made even more problematic by urging trustees to exercise legal powers that they have never before routinely exercised.

It would be a mistake to play the ostrich, hoping all this poppycock will melt into air. It is tempting to think that organizations like ACTA are too extreme to be effective, and it is galling to grant their sophistry the legitimacy of a response. Unfortunately, they are politically effective. For instance, many powerful friends and former colleagues of Cheney's buttress ACTA. The former president of the University of Colorado, Hank Brown, helped found ACTA when it was known as the National Alumni Forum 
(McAllister; ACTA, “Alumni”). Brown became the university's president when its previous president, Elizabeth Hoffman, was forced to resign, in good part because of the Churchill controversy that ACTA did so much to hystericize. ACTA's current chairman, Jerry Martin, worked on Brown's staff when he was a Republican senator from Colorado (Florida). A former chair of the philosophy department of the University of Colorado, Boulder, Martin also worked at the NEH when it was headed by Cheney (ACTA, "Jerry L. Martin”), who herself holds a master's degree from the university and is chairman emeritus of ACTA's National Council. Anne Neal, who holds a Harvard law degree, was general counsel to the NEH during Cheney's tenure and has been appointed by the secretary of education to the National Advisory Committee on Institutional Quality and Integrity, the panel responsible for reviewing accrediting agencies (Wilson; Lederman). Like the former Colorado governor Dick Lamm, who is the National Council's vice chairman, the current governor of Colorado, Bill Owens, is active in ACTA (McAllister). According to Emma Pérez, Owens hosted an ACTA conference for state trustees and appointed an ACTA coordinator to the board of trustees for Mesa State College when the board was restructured. (ACTA invites appointing committees for trusteeships to consult them for the names of ACTA-approved nominees.) This is only what I happen to know about the accomplishments of ACTA, which is only one such right-wing agency, in only one of its target states. ACTA's Web site lists accomplishments that it takes public credit for in other target states. The site includes a description of the Governor's Project, in which the council notes that its most effective work is done in behind-the-scenes networking - exactly the way it has operated in Colorado. Besides Brown, ACTA claims special success with "Virginia Governor Jim Gilmore, Governor George Pataki and Mayor Rudolph Giuliani ..., and Florida Governor Jeb Bush" (“Governor's Project").

ACTA is but one organization stumping for external control of higher education faculties. Funding for the National Association of Scholars (NAS) dwarfs ACTA's and comes from the very same sources (Media Transparency). In fact, NAS President Stephen Balch is also a director at ACTA, a fact that neither not-for-profit organization's IRS Form 990 indicates on line 80, where one might expect to see it. In 2001 the Colorado Commission on Higher Education paid NAS \$25,000 to review the University of Colorado's education program. Drawing on NAS's review, the commission voted to approve only eleven of the university's fifty-five academic majors for elementary education students. The Colorado Springs Independent reported, "Some of the majors disallowed by the Commission included American studies, astronomy, chemistry, fine arts, geology, business, music, 
philosophy, political science, psychology, sociology, classics, religious studies, women's studies, environmental studies, ethnic studies, Asian studies and all foreign languages" (Campbell). The NAS first made a name for itself in Texas in 1990, at the University of Texas, Austin, when it successfully blocked an English course on civil rights readings that had been proposed in response to increased incidents of racial and sexual harassment (People, Buying 15). Blocking one English course may not seem serious from one perspective; from another, this external interference was a grave breach of academic freedom.

Organizations like NAS and ACTA do not present well-reasoned arguments backed by good evidence, but they don't need to. Their objective is not to win a legitimate debate but to incite fear, muddy the water, and activate prejudice. At the end of the day, these objectives are adequate as long as their audience doesn't have the critical-thinking skills that liberal arts programs should be teaching students. We need to know what kind of arguments groups like ACTA make, but it should not be educators' goal to rebut ACTA itself (or Horowitz, the NAS, etc.). Instead, our goal should be to persuade various publics of the nullity of ACTA's arguments and to suffuse classrooms, campuses, and local and national media and legislatures with a deep understanding of traditional academic freedom's value to professors, students, and society and of the ways in which our curricula produce literate and culturally sophisticated graduates who contribute not only to the labor force but also to the nation's enjoyment and livability, its cultural life and vitality. It is especially critical that we articulate the value of academic freedom for students. Professors might include in their syllabi a statement on academic freedom-perhaps their university's official statement or that of the Global Colloquium of University Presidentsand discuss it in class so that students understand how academic freedom assures them the best education professors can provide them with. It is a violation of all students' academic freedom to coerce professors to downgrade course work to appease philistine political interests, even if the coercion originates from the transient discomfort of an individual student who, for whatever reason, objects to course work. Individual students do not have a right to be free from discomfiture in the classroom; all students do have a right to professors' best educational judgment. Students with objections are perfectly free to enter grievance procedures or, on the consumerchoice model they may prefer, to buy a degree from a for-profit institution that will cater to their whims.

Students are key to the current debate over academic freedom, for today's opponents of academic freedom take a theological view of American patriotism, fearing that students will be led to doubt by professors' 
questions about the Western tradition and United States history. Such opponents play to parents' fear that their children will be corrupted or otherwise hurt and, to protect patriotic orthodoxy, do not scruple to make the most frenzied charges they can work themselves up to in the hope that some little bit of the mud thus slung will stick. In an introductory segment to an interview with Horowitz on the 700 Club, Pat Robertson called professors

termites that have worked their way into our academic society, and it's APPALLING. ... They are racists, murderers, sexual deviants and supporters of Al-Qaeda- and they could be teaching your kids! . . . These guys are out and out communists, they are radicals, they are, you know, some of them killers, and they are propagandists of the first order. ... $[\mathrm{Y}]$ ou don't want your child to be brainwashed by these radicals, you just don't want it to happen. Not only brainwashed but beat up, they beat these people up, cower them into submission. AGGGHHH!!!!

(People, "Pat Robertson")

The accusation of racism will no doubt surprise those who are also criticized for teaching antiracist courses. If it were only Robertson raving, the incident would not merit mention, and one might think that even Horowitz would not stoop this low. In fact, the man who has succeeded in putting Academic Bill of Rights legislation on the agenda in numerous states-the man whose Los Angeles-based not-for-profit Freedom Center (formerly the Center for the Study of Popular Culture) reported $\$ 4.56$ million in revenue in 2006 (David Horowitz) - concurred with Robertson, denounced the academy's alleged political bias as a bigger scandal than Enron, and estimated that fifty thousand to sixty thousand professors support terrorism. Horowitz expressed dismay at professors' supposedly enormous six-figure salaries and six-hour work week, and he wanted the audience to know that professors in the humanities generally do have salaries on the order of $\$ 300,000$ and work six hours a week, eight months a year. He routinely blames professors' Brobdingnagian salaries for the rise in college costs, ignoring such real-world factors as state legislatures that slash funding for higher education and, in states such as Colorado, push through taxpayer bill-of-rights legislation to forestall future efforts to restore funding. In reality, about sixty-five percent of the nation's higher education faculty members are now contingent or part-time and may cobble together as many as twelve courses a year to earn a livable income, the equivalent of teaching a full course's worth of material every month. By one estimate, "median hourly wages for part-time faculty in 2003 range[d] from a low of $\$ 11.19$ at public two-year colleges to a high of $\$ 20.24$ at private doctoral 
universities" (AAUP, Devaluing 33). The average salary of all disciplines' full professors, a minority in the teaching corps, was \$94,738 in 2005-06 (Survey Report Table 4). Full professors, of course, have spent decades studying for the doctorate, competing for jobs, teaching thousands of students, and publishing research. As senior members of the profession, they naturally earn higher average salaries. But, among them, professors in the humanities are not known for earning the highest salaries. In this context, it is not hard to guess why Horowitz failed to mention his own 2006 salary of $\$ 509,000$ while railing against the salaries of humanities professors (David Horowitz).

Academic freedom's opponents refuse civil discourse itself and, as Michael Bérubé notes, reject procedural liberalism, too, "the idea that no one political faction should control every facet of a society." What I hope for is not a solid, rational critique that will persuade Robertson and Horowitz that their goals are double-plus ungood. Instead, I hope for classrooms, campuses, and communities full of students who will themselves understand the condescending paternalism of efforts to "protect" them from controversy. To convey to students a deep sense of what traditional academic freedom is and is good for, we need to have a deep sense of what its fault lines are.

\section{The Paradox of Academic Freedom}

With that goal I turn to what Domna Stanton calls "the paradox of academic freedom." We immediately encounter problems clearly presenting academic freedom's value, because academic freedom is, to borrow Michel Foucault's phrase from another context, an "utterly confused category" for freedomites and unfreedomites alike (101). Joan Scott and Judith Butler have each explored the ways in which disciplinary norms act not only to ensure the quality of academic work but also to enforce uniformity. About Glenn Morrow's 1968 definition, Scott writes:

[A]cademic freedom rests on the protection afforded individuals by their disciplines against "incompetent outside authorities." What is ignored is the possible conflict between "mutual criticism" and the selection of new members "through disciplined and systematic training." Morrow, like Dewey, makes the correction of error, argument about interpretation, and the "approval and disapproval" of peers an entirely positive dimension of scholarly activity. But the inseparable other side of that regulatory and enabling authority is that it secures consensus by exclusion.... [D]iscipline is at once productive-it permits the organization of knowledge and it authorizes knowledge producers—and confining — it installs 
explicit and tacit normative standards which, when they are understood to be provisional, can serve important mediating functions, but which, when they are taken as dogmatic precepts, become instruments of punishment. The two aspects cannot be disentangled; discipline functions in a necessarily paradoxical way.

(169-70)

To this paradox, we can add several more:

the legal question of academic freedom's status as an individual or institutional right, a question introduced in 1957 by the reference in Justice Felix Frankfurter's concurring opinion to " the four essential freedoms' of a university-to determine for itself on academic grounds who may teach, what may be taught, how it shall be taught, and who may be admitted to study" (Sweezy 263; emphasis added);

the curious United States arrangement of trustees being, legally, the institution itself, which vests academic freedom in persons who may have no academic credentials and who may, legally, dismiss faculty members on any grounds or none unless otherwise bound by contract or curbed by the First Amendment at public institutions;

the supposed conflict between faculty members' and students' academic freedom; and

the irony that some of the strongest statements in academic freedom's favor have entered the legal lexicon through dissenting opinions, including those of the Great Dissenter himself, Oliver Wendell Holmes, whose dissenting opinion in Abrams v. United States introduced the notion of a marketplace of ideas as the best test of truth.

Other contradictions, ironies, and paradoxes could be extracted from academic freedom's messy history in academe, scholarly associations, and the courts, in the United States and abroad. These internal fissures threaten to undermine academic freedom in a time when adjunct labor without the protection of tenure constitutes an increasing percentage of the faculty (Laurence; AAUP, Contingent), when funding for higher education is increasingly privatized (Doumani, "Between Coercion"; Frydl; "Report of the ADE Ad Hoc Committee"), and when state and federal officials invoke terrorism to abridge constitutionally guaranteed civil rights. (On legal definitions of academic freedom, see Byrne; Van Alstyne.)

I stress these conditions-reliance on adjunct labor, privatization of higher education, and post-9/11 state surveillance-because in this article I can only address one brief point about each.

1. The AAUP has long defined academic freedom hand-in-glove with tenure, a protection against illegitimate dismissal. The public, notes Richard Mulcahy, is today suspicious of this "job security," and we cannot count on support for it without a major enlightenment campaign (156). To the extent that the tenure- 
stream faculty, bribed by lower teaching loads or exclusively upper-division and graduate courses, is complicit in allowing adjunct labor to become the norm in higher education, tenure and academic freedom with it will have been eliminated, not with a bang but with the whimper of underemployed PhDs.

2. Kathleen Frydl argues, "Privatization is the most far-reaching answer to the critical challenge posed by the research university: who shall exercise sovereignty over it, and by what logic? This - and not speech outside the classroom - is the front line of academic freedom" (179). She predicts that "the future of academic freedom will be not in the courts but in budgets" (195).

3. Post-9/11 abridgments of civil rights and cutbacks in funding certain subjects threaten to chill or starve research, notably area studies. Beshara Doumani's Academic Freedom after September 11 includes several essays that ask trenchant and disquieting questions about research in such an atmosphere of state surveillance (Doumani, "Between Coercion"; Butler; Newhall; Beinin). Librarians vigorously resisted such surveillance. As a result, an outlandish smear campaign accused them of supporting terrorism (Ballon; Kaplan; Walfield). An anecdote of particular hilarity involved the Patriot Act's provision that libraries might be required to secretly hand over patron records. Consequently, some librarians chose to post signs that were legal under the letter if not the spirit of the law, such as one that said in large type "The FBI has not been here" and in small type "[watch very closely for the removal of this sign]" (Talbot; FBI).

We find none of this levity in Robert Post's stern analysis of the faculty's lackadaisical defense and understanding of academic freedom. Post fears that

[t]he triumph of the [AAUP's] "1915 Declaration" has been so complete that we have grown soft and complacent. We have come all too easily to assume academic freedom as our "God-given right" and have become oblivious to its distinct justifications and limitations. We have lost touch with the many ways in which the academic freedom we ... enjoy is rooted in progressive-era ideas about the function of the university, the role of professional expertise and self-regulation, and the preconditions for the production of knowledge.

We no longer live in the progressive era, Post reminds us, and we cannot afford to forget it. In this respect, John Dewey's 1902 essay “Academic Freedom" poses useful historical cautions as well as possible keys to our current situation. Dewey confidently assures us, "The university function is the truth-function" (55). What this meant for Dewey surely is not what academics might take it to mean today. We rely less than Dewey on a notion of science as inevitable progress toward absolute certainty, in which some fields are said to be emerging, partial sciences that will eventually achieve the unquestionable certainty of "mathematics, astronomy, physics, or chemistry," against which "there is no leverage ... to direct an attack 
upon academic freedom" (55-56). Bear in mind that Dewey wrote this in 1902. Anyone familiar with the course of physics since 1905, in even a superficial lay capacity, will find this statement extraordinary, and the difference that it marks from today is one instance of the very difference to which Post refers. Nor did Dewey's prediction prove accurate that biology would quickly free itself from the opposition of anti-Darwinist superstition, which nowadays goose-steps under the banner of intelligent design.

When the pursuit of truth and knowledge is no longer understood as an inevitable approach to absolute certainty, the concept and foundation of academic freedom must change. It must become not only more complex but also paradoxical. (This is not, as Gertrude Himmelfarb foolishly suggests, to deny "that there is any such thing as knowledge, truth, reason, or objectivity" [97].) To what authority does academic freedom appeal, if not to that of "definitive method" and "verified fact" (Dewey 56)? Post describes the kind of bind that the situation places us in:

Professional norms are needed to constrain the exercise of academic freedom so as to connect that freedom to the production of knowledge, and yet professional norms are also themselves forms of knowledge that are best advanced when debated with the kind of dissent that requires academic freedom. Academic freedom thus appears to be simultaneously limited by and independent of professional norms.

Worse, professional judgment itself is amenable to enduring difference of opinion (even in physics), exposing it to "suspicion and distrust" (Post 77). Academic freedom's opponents exploit this weakness for all it's worth: contemporary academics are all politicized relativists who have no standards, they declare; "academic freedom" (still in Buckley's 1951 scare quotes) is merely a screen behind which professors do as they please in the classroom, unconstrained by fidelity to rigorous standards of truth.

A redoubtable defendant of academic freedom, Post is acutely aware of the danger involved in allowing such ideas to flourish, and he believes them to be nourished by popular and legal understandings of academic freedom as an individual right derivative of, or "a special concern of," the First Amendment, as certain key judicial decisions suggest (Keyishian 603). Despite these prominent legal rulings and popular understandings of academic freedom as inhering in individual professors, Post observes that "no university currently deals with its faculty as if academic freedom were an individual right"; instead, faculty members are subject to disciplinary review (78). At every stage in scholars' careers, their practices—including teaching and student learning-are subject to "a normative account of the kind and nature of relevant professional knowledge." In Post's view, the 
necessity of a professional judgment of relevance "strongly suggests that the distinction between education and indoctrination is largely internal to academic standards" and that it must therefore remain a corporate responsibility of the faculty, not the purview of an individual (81). Post is not innovating here. "The university would have a certain autonomy (since only scholars can pass judgment on scholars as such)," wrote Kant in 1794, "and accordingly it would be authorized to perform certain functions through its faculties" (Conflict 23; emphasis modified).

This corporate responsibility can provide powerful protection to faculty members who undertake controversial work, as scholars had already discovered in the medieval European university (Hofstadter 3-11). On the other hand, such responsibility might also be construed, Scott reminds us, to imply "that in order to protect the autonomy of the teaching establishment from 'outside' interference, it had to clean its own house by purging politically suspect teachers. On this definition, the greater good of the profession required the sacrifice of its most unconventional or troublesome members" (164). This is precisely what activist groups like ACTA hope to instill in faculty members: a sense that they must, if they wish to protect their freedom, rid the academy of those who attract unwanted attention. In this vein, the "Report of the Investigative Committee" on Ward Churchill wrote that "public figures who choose to speak out on controversial matters of public concern naturally attract more controversy and attention to their background and work than scholars quietly writing about more esoteric matters that are not the subject of political debate" (4). In saying so, the committee meant to answer Churchill's allegation that he was being inappropriately targeted, but the mere fact that controversy does attract attention does not mean that controversy does not attract reprisal. The principle of academic freedom protects against reprisal (the subject of Churchill's claim), not against heightened scrutiny (the subject of the committee's response). I have no position on the committee's recommendations or the quality of Churchill's scholarship; however, I do find the committee's cautionary note on attracting controversy discomforting. It is easy to discern in it the possible message that unpopular scholarship or public speech is undertaken at the individual scholar's risk without benefit of the corporate faculty's protection. There is advantage here in Post's corporatetraditionalist (rather than individualist-First Amendment) argument for understanding and protecting academic freedom.

Churchill's case also raises the tortuous question of intramural versus extramural speech. Advocacy groups such as ACTA and Horowitz's Freedom Center most commonly state objections to professors' influence over students in the classroom-intramural speech that has typically been 
constrained only by consideration of students' maturity (AAUP, “General Report" 35), the professor's expertise, and the material's relevance to course work. By contrast, extramural speech has traditionally had weaker protection and in Kant's view carried no protection whatsoever. Tellingly, ACTA and Horowitz are actually more likely to quote professors' so-called extramural speech than their intramural speech. Now, I take popular faculty opinion to be that academic freedom ensures faculty members the right to express whatever controversial notion comes into their heads, inside or outside the classroom, regardless of how tenuous or tendentious the notion might be. But in reality academic freedom affords faculty members, in Post's words, "less liberty than that enjoyed by ordinary citizens" in expressing opinions publicly because of the obligations their profession imposes on them to be circumspect, accurate, respectful, and so on, obligations the lay citizen does not bear (85). At state institutions, faculty members nevertheless have-over and above the protection of academic freedom-the full protection of the First Amendment from administrative reprisal against extramural speech. However, faculty members at private institutions do not have First Amendment protection against administrative reprisal-a distinction too often forgotten and one that seriously throws into disarray recourse to the First Amendment as a basis for academic freedom, unless we are willing to say that faculty members at private institutions have no claim to it or have only a metaphorical claim to it. Moreover, Derrida reminds us in "The University without Condition" that the "transformation under way in public cyberspace, which is public on a worldwide scale, beyond state-national frontiers" makes the intramural-extramural distinction "more archaic and imaginary than ever" (220). In any event, the AAUP's 1940 statement dropped a 1925 clause requiring a committee to evaluate "doubtful extramural utterances" because it was impossible to enforce (Metzger, Age 490), and the 1940 statement is generally cagey on the question of extramural speech, committing itself to very little. Although an adherence to something like an intramuralextramural distinction comes down to us from Kant, we can only conclude with Derrida that the distinction "has never been . . . either tenable or respectable, in fact or by law" "University" 220). It may be that this wall's effective absence means that professors are professionally accountable for their speech in most circumstances.

Academic freedom, then, should be understood in terms of the corporate faculty's right and in terms of a professional expertise that is as carefully delimited as possible. Examining actual university practices shows immediately that the academy locates the authority that bestows the right of academic freedom in a complex network of disciplinary apparatuses. 
These extend from graduate admissions committees through course work, teaching assistants' training, comprehensive exams, professionalization activities, the dissertation, conference presentations, peer review for publication, job interviews, tenure reviews, book reviews, promotion procedures, annual reviews, student evaluations, and service on professional committees and in regional, national, and international associations. Where any one of these controls has weakened, institutions are well advised to redress the weakness to maintain their credibility and accountability. The system is far from perfect, but it does include an extensive battery of controls to enforce the norms of academic inquiry on individuals at the same time that it lends them a special autonomy: it imposes duties in exchange for rights. Indeed, Thomas L. Haskell suggests that professors' work is subjected to "competition more severe than would be thought acceptable in ordinary human communities," not "sheltered" as academic freedom's detractors suggest (47). The basic unit in this competitive system is the department, which is in turn an imprecise administrative embodiment of the more abstract discipline, to which faculty members answer in principle. "Academic freedom, as it is now structured," argues Louis Menand,

depends crucially on the autonomy and integrity of the disciplines. For it is the departments, and the disciplines to which they belong, that constitute the spaces in which rival scholarly and pedagogical positions are negotiated. Academic freedom not only protects sociology professors from the interference of trustees and public officials in the exercise of their jobs as teachers and scholars; it protects them from physics professors as well.

("Limits"17)

If the disciplines' autonomy and integrity safeguard the duties and rights of academic freedom, then what do we make of the academy's commitment to interdisciplinary study, which is nowadays trumpeted on every possible occasion? Are we in a pickle if interdisciplinarity is the future of the university at the same time that the future of academic freedom depends on the autonomy and integrity of the disciplines? There are two points to be made here. The first is that interdisciplinarity does pose a challenge to academic freedom when faculty members' research and teaching cross disciplinary lines in ways that set their methodology at odds with one or more of the disciplines that retain the authority to adjudge the merit of that research and teaching. This is not news. Everyone has known for a long time that academic judgment in an interdisciplinary context can treacherously morph into disciplinary "grudgment."

The second point is more interesting. Interdisciplinarity raises in especially salient ways the ever-present question of which academic norms to 
apply in a given instance and how they should be understood to bear on the work to be evaluated; in fact, it suggests that the appropriate disciplinary norms, as such, do not preexist the work, which takes place in disciplines' interstices. In some forms, interdisciplinarity becomes antidisciplinarity and refuses any existing standards of disciplinarity, subjecting these to a radically heterodox critique. Assuming rigorous standards, such "radical heterodoxy" is exactly what academic freedom should protect (Van Alstyne 123), but how are we to judge the rigor of the standards when the critique takes place outside existing norms, when it refuses what the "autonomy and integrity of the disciplines" admit as norms? Before answering that question, I want to allow space for Menand's caveat:

Administrators faced with allocating dwindling resources in the period of retrenchment that now seems upon the American university will be delighted to see the disciplines lose their authority, for it means spreading fewer faculty farther, and it gives them far greater control over the creation and elimination of staff positions.

("Limits" 18)

Or, he asks:

Why support separate medievalists in your history department, your English department, your French department, and your art history department, none of them probably attracting huge enrollments, when you can hire one interdisciplinary super-medievalist and install her in a Medieval Studies program, whose survival can be made to depend on its ability to attract outside funding?

("Marketplace")

As Menand understands it, academic freedom's ability to shelter heterodox interdisciplinarity can grant an orthodoxy to the administrative dismantling of the humanities.

Menand points to a very real danger, but it is not the whole story. As Butler writes, "To question existing norms is not the same as questioning the existence of norms in general or calling for a postnormative mode of academic inquiry" (114). To admit contingency or challenge disciplinary authority is not to dispense with disciplinary authority any more than deconstructing truth is doing away with it. We have seen that even when attacks on academic freedom such as ACTA's aim at individuals-Ward Churchill being the poster boy par excellence-they aim beyond them at the faculty and not only at the faculty of the individuals' interdisciplinary programs but at the humanities and social science faculties as a whole, not only at the University of Colorado but at all United States institutions, public and private. Even while admitting that Churchill is anomalous in sundry ways, they assert him as the norm. In The Professors: The 101 Most 
Dangerous Academics in America, a book that Cary Nelson exhorts us to ignore, Horowitz admits that "it is a reasonable assumption that a majority of faculty members are professionals and devoted to traditional academic methods and pursuits" (xxvii); nonetheless, he argues that a cherry-picked handful of professors is representative of the nation's faculty as a whole and explicitly attributes the influence that they have to the fact that many of them teach in interdisciplinary areas. "Because activists ensconced in programmatic fields like black studies and women's studies also teach in traditional departments like history and English," Horowitz believes their influence in the academy is dramatically enhanced (xxv). In effect, they are synonymous with the faculty at large even if they are anomalous, since they have metastasized throughout the faculty body through the malignant agency of interdisciplinarity. In this strange view, which ACTA shares, Ward Churchill's work is exceptional but also the very model of a postmodern major in general.

Jingoism and opposition to academic freedom did not begin on September 11, 2001. They did gain new footholds then, however, and have since taken more precise aim at the humanities and social sciences—and at ethnic and area studies in particular, two interdisciplinary fields of special interest to many of us in the modern languages. Many hotheaded people said many intemperate things following 9/11, but only Churchill acquired nationwide iconic status among those seeking to stymie controversial academic work. I attribute Churchill's iconicity to his interdisciplinary location in ethnic studies, his own disputed ethnicity, and long-standing official repression of Native American history. (Again, the issue of Churchill's sketchy scholarship is immaterial here, except insofar as its alleged weakness may have delighted those who exploited it for controversy.) It is unfortunate but not surprising that after 9/11, in Paul Gilroy's words, "[x]enophobia and nationalism are thriving" (2). Colliding with the powerful antiracist critiques of the past centuries, the new xenophobia and nationalism give rise to what Gilroy calls "complex, proteophobic, and ambivalent patterns" of human valuation and devaluation (37). It is easy to see how explosive a figure Churchill is when we consider, as Gilroy asks us to, that

wherever they were applied, the colonial techniques of indiscriminate mass destruction ended up being closer to the work of extermination than control and settlement. In this bloody sequence, the doctrine of preemptive strikes and the systematic refusal to distinguish combatants from civilians have acquired an elaborate and multinational prehistory.

These are hard truths to confront, and Gilroy names the inability or refusal to come to terms with them "postcolonial melancholia." His analysis 
of the sort of ethnic reprisals that have followed 9/11 provides an uncanny diagnosis of the particular focus of current attacks in the United States on ethnic studies. Because academic freedom is authorized by the contingent norms of the disciplines, not individual professors, its opponents must direct an attack not only at individuals but also through and beyond them at higher education as a whole. Interdisciplinary work epitomizes the corporate faculty's responsibility for academic freedom precisely because it transcends the boundaries of the traditional units of disciplinary authority. Meanwhile, "proteophobic" post-9/11 ethnic animosity fuels jingoism. In this way, interdisciplinary programs in ethnic studies afford selfproclaimed patriots like ACTA and Horowitz a privileged location from which to attack the credibility of the corporate faculty.

But the attack typified by How Many Ward Churchills? is only the bottom-up prong of the assault on academic freedom. As noted earlier, its opponents are also plotting top-down thrusts. David Rabban warns, "Another terrorist attack on the United States ... could easily increase pressures on academic and political expression that have mostly been resisted" (xiii). To this danger, we should add that of another economic downturn, since, as Frydl argues, financial interests will increasingly determine the future of academic freedom. Whereas attempts to dictate directly to individual faculty members have "mostly been resisted," top-down efforts like ACTA's to influence governors, trustees, and wealthy alumni donors have been at least partially successful because they primarily take aim not at faculty governance or specific classrooms but at the folks who hold the purse strings, with which they can strangle anyone they care to. For his part, Derrida urged us to consider that, to the extent that the university undertakes its work "absolutely independent" of economic interest, it "is also an exposed, tendered citadel, to be taken, often destined to capitulate without condition, to surrender unconditionally" ("University" 206). He posed the paradox as a question: how can the faculty claim unconditional sovereignty over its work, divorced from economic interest, and not expect that work "to let itself be taken over and bought at any price"? To pose his question more crassly, how can the university faculty defend its intellectual sovereignty, which needs funding, over and against what Buckley named, decades ago, the "sovereignty of the consumer"?

One answer is of course that under the logic of late capitalism nothing, including the principle of academic freedom, remains unpenetrated by commodification, that everything will only be ever more thoroughly commodified, and that in a postindustrial information economy, intellectual work is the premier commodity, not the one form of work preserved from commercial contamination. This would be an immobilizing conclusion if it 
were all there is left to say, but Derrida's purpose in "The University without Condition" is to marshal an "unconditional resistance" from within the humanities "to all the powers of dogmatic and unjust appropriation ... to all the powers that limit democracy to come" (204-05). The humanities are the privileged space of academic freedom's defense and definition precisely because the truth as such has been most vigorously debated in the humanities. If academic freedom protects the right to the pursuit of truth and knowledge, it is in the humanities that we learn what we are pursuing. And to the extent that language is the ground of the human figure, the field of language and literature is the epicenter of the humanities. (Think of Diderot's Rêve de d'Alembert in which Cardinal de Polignac exclaims to an orangutan in a glass cage, "Speak! And I will baptize you" - an anecdote that is no longer so farfetched as Mlle de Lespinasse must have thought it [675; my trans.].)

To shoulder "truth" and "the human" is a tall order and one that demands disciplinary flexibility in the humanities and the freedom to range into the social sciences, law, the natural sciences, theology, and medicine. It demands the very free range that Kant claims for philosophy in The Conflict of the Faculties, where he offers a definition of philosophy that sounds a lot like the humanities at large: "a science of man, of his representations, thoughts and actions" (127). In this vein, we might pastiche Derrida: "there is no outside-the-humanities" "Il n'y a pas de hors-texte" [De la grammatologie 227]). The pastiche may seem flippant, but in the age of genocide and terrorism the notion that nothing human could be alien to us as humanists in the world's sole superpower could not be more relevant. This relevance is exactly what many in the humanities have wanted to engage when they have been accused of impertinent politicking in the classroom: to ask if language can be more adequate to the truth; to ask if history has been recounted truthfully; to discern the alien as human; to learn the language and culture of the other; to explore the history of the inhuman/e in the human/e; to demand an expansion of human rights; to interrogate the border rather than the human being at the border; to discover what rhetorics of language and image mobilize a border around who counts as human; to question who is patrolling the border and with what ends. These questions can only be impious.

\section{NOTE}

1. I learned of this spine-tingling outburst in Henry Giroux's article. In the body of my essay, I have quoted the version of the interview transcript posted on People for the American Way's Web site, where a video clip is also available ("700"). There is a tamer 
transcript of the interview on the CBN News Web site (CBN News). The video clip appears to be a segment introductory to the interview itself. Both Giroux's transcript and that of People for the American Way appear to be of the introductory segment, not the interview itself; however, Giroux cites as his reference the tamer CBN News transcript of the interview itself.

\section{WORKS CITED}

Adorno, Theodor. Kant's Critique of Pure Reason. 1959. Ed. Rolf Tiedemann. Trans. Rodney Livingstone. Stanford: Stanford UP, 2001. Print.

American Association of University Professors. AAUP Contingent Faculty Index 2006. AAUP, Dec. 2006. Web. 12 Dec. 2006.

- The Devaluing of Higher Education: The Annual Report on the Economic Status of the Profession, 2005-06. AAUP, Mar.-Apr. 2006. Web. 30 Nov. 2006.

. "General Report of the Committee on Academic Freedom and Academic Tenure [1915 Report]." Metzger, American Concept 16-43.

American Council of Trustees and Alumni. "Alumni Organize to Preserve Free Speech and Free Thought at Colleges and Universities." ACTA, 17 Mar. 1995. Web. 12 Dec. 2006. 2007.

—. How Many Ward Churchills? ACTA, 2006. Web. 16 Aug. 2006.

. "Jerry L. Martin.” ACTA, n.d. Web. 1 Oct. 2006.

. "Mission and History." ACTA, n.d. Web. 17 Oct. 2006.

Ballon, Marc. "Library Group Draws Fire over Web Site.” Fewish fournal 20 Jan. 2006: n. pag. Web. 30 Nov. 2006.

Beinin, Joel. "The New McCarthyism: Policing Thought about the Middle East." Doumani, Academic Freedom 237-66.

Bérubé, Michael. "What Does ‘Academic Freedom' Mean?” Academe Nov.-Dec. 2006: n. pag. Web. 23 Sept 2008.

Buckley, William F. God and Man at Yale: The Superstitions of "Academic Freedom." Chicago: Regnery, 1951. Print.

Butler, Judith. "Academic Norms, Contemporary Challenges: A Reply to Robert Post on Academic Freedom." Doumani, Academic Freedom 107-42.

Byrne, Peter J. "Academic Freedom: A 'Special Concern of the First Amendment.' " Yale Law fournal 99.2 (1989): 251-40. Print.

Campbell, Bob. "State Education Commission Coming under Fire." Colorado Springs Independent 24 May 2001: n. pag. Web. 28 Sept. 2006.

CBN News. "The 101 Most Dangerous Professors in America." CBN, n.d. Web. 4 Oct. 2006.

Chamberlain, John. Introduction. Buckley n. pag.

Cronin, Mike. "Conservatives Push to Counter Liberal Professors." Arizona Republic 12 Aug. 2006: n. pag. Web. 18 Oct. 2006.

David Horowitz Freedom Center. 2006 Form 990. GuideStar. GuideStar, n.d. Web. 23 Sept. 2008.

Derrida, Jacques. De la grammatologie. Paris: Minuit, 1967. Print.

—. Du droit à la philosophie. Paris: Galilée, 1990. Print. 
- "The University without Condition." Without Alibi. Trans. Peggy Kamuf. Stanford: Stanford UP, 2002. 202-37. Print. Trans. of L'université sans condition. Paris: Galilée, 2001.

Dewey, John. "Academic Freedom.” 1902-1903. Ed. Jo Ann Boydston. Carbondale: Southern Illinois UP, 1976. 53-66. Print. Vol. 2 of The Middle Works, 1899-1924. 15 vols. 1976-83.

Diderot, Denis. Le rêve de d'Alembert. Philosophie. Paris: Laffont, 1994. 601-86. Print. Vol. 1 of Euvres.

Doumani, Beshara, ed. Academic Freedom after September 11. New York: Zone, 2006. Print.

—. "Between Coercion and Privatization." Doumani, Academic Freedom 11-57.

Fain, Paul. "Surveys Find Governing Boards Are Older and Slightly More Diverse." Chronicle of Higher Education 1 July 2005: A21. Print.

FBI Sign. N.p., n.d. Web. 9 Oct. 2006.

Florida Department of Education. "Jerry L. Martin." Florida Dept. of Educ., n.d. Web. 1 Oct. 2006.

Foucault, Michel. An Introduction. Trans. Robert Hurley. New York: Vintage, 1978. Print. Vol. 1 of The History of Sexuality.

Frydl, Kathleen J. "Trust to the Public: Academic Freedom in the Multiversity." Doumani, Academic Freedom 175-202.

Gerstmann, Evan, and Matthew J. Streb, eds. Academic Freedom at the Dawn of a New Century: How Terrorism, Governments, and Culture Wars Impact Free Speech. Stanford: Stanford UP, 2006. Print.

Gilroy, Paul. Postcolonial Melancholia. New York: Columbia UP, 2005. Print.

Giroux, Henry A. "Academic Freedom under Fire: The Case for Critical Pedagogy." College English 33.4 (2006): 1-42. Print.

Global Colloquium of University Presidents. "Statement on Academic Freedom." Columbia U, 26 May 2005. Web. 23 Dec. 2006.

Haskell, Thomas L. "Justifying the Rights of Academic Freedom in the Era of 'Power/ Knowledge.'” Menand, Future 43-90.

Himmelfarb, Gertrude. "The New Advocacy and the Old." Spacks 96-101.

Hofstadter, Richard. The Age of the College. Hofstadter and Metzger 1-274.

Hofstadter, Richard, and Walter P. Metzger. The Development of Academic Freedom in the United States. New York: Columbia UP, 1955. Print.

Horowitz, David. The Professors: The 101 Most Dangerous Academics in America. Washington: Regnery, 2006. Print.

Kant, Immanuel. "An Answer to the Question: 'What Is Enlightenment?'” Political Writings. Ed. Hans Reiss. Trans. H. B. Nisbet. 2nd ed. Cambridge: Cambridge UP, 1991. 54-60. Print.

. The Conflict of the Faculties (Der Streit der Facultäten). Trans. Mary J. Gregor. Lincoln: U of Nebraska P, 1979. Print.

Kaplan, Lee. "Librarians for Terror." Front Page Magazine 24 Aug. 2004: n. pag. Web. 30 Nov. 2006.

"Keyishian et al. v. Board of Regents of the University of the State of New York." 1967. Metzger, Constitutional Status 589-629.

Laurence, David. "The Demography of the Faculty, 1993-2004." ADE Bulletin 138-139 (2005-06): 3-14. Print. 
Lederman, Doug. "Stacking the Deck?" Inside Higher Ed 1 May 2007: n. pag. Web. 8 May 2007.

Lieberman, Joe. "Letter to ACTA." Nation 17 Jan. 2002: n. pag. Web. 17 Oct. 2006.

Martin, Jerry L., and Anne D. Neal. Defending Civilization: How Our Universities Are Failing America and What Can Be Done about It. Rev. ed. ACTA, Feb. 2002. Web. 30 Nov. 2006.

Martin, Jerry L., Anne D. Neal, and Michael S. Nadel. The Shakespeare File: What English Majors Are Really Studying. ACTA, Dec. 1996. Web. 30 Nov. 2006.

McAllister, Bill. "Friends in High Places Should Benefit Ex-CU Professor." Denver Post 6 Sept. 2000: F1. Print.

Menand, Louis, ed. The Future of Academic Freedom. Chicago: U of Chicago P, 1996. Print.

—. "The Limits of Academic Freedom." Menand, Future 3-20.

. "The Marketplace of Ideas." American Council of Learned Societies. Occasional Paper 49. ACLS, 2001. Web. 10 Oct. 2006.

Metzger, Walter P. The Age of the University. Hofstadter and Metzger 275-506.

, ed. The American Concept of Academic Freedom: A Collection of Essays and Reports. New York: Arno, 1977. Print.

—, ed. The Constitutional Status of Academic Freedom. New York: Arno, 1977. Print.

Morrison, Toni. Nobel lecture. Nobelprize.org. Nobel Foundation, 7 Dec. 1993. Web. 21 Oct. 2006.

Mulcahy, Richard. "A Full Circle: Advocacy and Academic Freedom in Crisis." Spacks 142-60.

Nelson, Cary. "Ignore This Book." Rev. of The Professors: The 101 Most Dangerous Academics in America, by David Horowitz. Academe Nov.-Dec. 2006: 81-85. Print.

Newhall, Amy. "The Unraveling of the Devil's Bargain: The History and Politics of Language Acquisition.” Doumani, Academic Freedom 203-36.

Pavela, Gary. "Academic Freedom for Students Has Ancient Roots." Chronicle of Higher Education 27 May 2005: B8. Print.

People for the American Way. Buying a Movement: Right Wing Foundations and American Politics. PFAW, 1996. Web. 1 Oct. 2006.

—. "Pat Robertson Calls Liberal Professors 'Racists, Murderers, Sexual Deviants and Supporters of Al-Qaeda." PFAW, 21 Mar. 2006. Web. 4 Oct. 2006.

—. "700 Club's Pat Robertson Comments on Liberal Professors." PFAW, 21 Mar. 2006. Web. 4 Oct. 2006.

Pérez, Emma. "Ward Churchill Is Neocon Test Case for Academic Purges." WBAI. WBAI, 15 Feb. 2005. Web. 1 Oct. 2006.

Post, Robert. "The Structure of Academic Freedom." Doumani, Academic Freedom 61-106.

Rabban, David. Foreword. Gerstmann and Streb ix-xiv.

"Report of the ADE Ad Hoc Committee on Changes in the Structure and Financing of Higher Education.” ADE Bulletin 137 (2005): 89-102. Print.

"Report of the Investigative Committee of the Standing Committee on Research Misconduct at the University of Colorado at Boulder concerning Allegations of Academic Misconduct against Professor Ward Churchill." U of Colorado, 16 May 2006. Web. 9 Oct. 2006.

Scott, Joan. "Academic Freedom as an Ethical Practice." Menand, Future 163-80. 
Spacks, Patricia Meyer, ed. Advocacy in the Classroom: Problems and Possibilities. New York: St. Martin's, 1996. Print.

Stanton, Domna. "The Paradox of Academic Freedom.” MLA Newsletter 37.3 (2005): 3-5. Print.

Survey Report Table 4. American Association of University Professors. AAUP, n.d. Web. 30 Nov. 2006.

"Sweezy v. New Hampshire." Metzger, Constitutional Status 234-70.

Talbot, Margaret. "Subversive Reading." New York Times 28 Sept. 2003: n. pag. Web. 23 Aug. 2006.

"Time Is of the Essence." Chronicle of Higher Education 6 Oct. 2006: A25. Print.

Van Alstyne, William W. "Academic Freedom and the First Amendment in the Supreme Court of the United States: An Unhurried Historical Review." Law and Contemporary Problems 53.3 (1990): 79-154. Print.

Walfield, Mike. "The ALA Library: Terrorist Sanctuary." Front Page Magazine 8 May 2003: n. pag. Web. 30 Nov. 2006.

Wilson, Robin. "A Not-So-Professorial Watchdog: Anne Neal Has Never Worked at a College, but She Has Become a Leading Critic of Left-Wing Faculty Members.” Chronicle of Higher Education 10 Nov. 2006: A10. Print. 